\title{
New Polish Geological and Mining Law
}

\author{
Mining law as environmental law
}

The main purpose of introducing the mining legislations (mining laws) has for many years been the determination who and on what conditions may explore the mineral deposits and carry out mining operations. The second aim of the above regulations has been the determination of safety standards. Mining operations usually are carried out in the environment that is unfamiliar to people, where unknown threats may occur. In the middle of the last century the third factor stimulating the development of mining legislations occurred. Mineral deposits are the components of the environment, so mining operations may be considered as operations using the environment. On the other hand, most mining operations cause damages to other components of the environment. As a result, mining legislation may be considered as a specific kind of environmental law.

* Ph.D., Prof. of University of Silesia, Katowice.

** MA, Mining Chamber of Industry and Commerce. 
Aleksander Lipiński, Katarzyna Lipińska

\section{Some historical remarks}

In Poland the law referring to mining activity has been strongly influenced by the country's history. Between 1795 and 1918 Poland was divided among its neighbours. ${ }^{1}$ It did not exist as an independent state until 1918 when it regained independence. At that time on the territories that before 1918 belonged to the partitioning powers the national laws remained in force. For instance, it meant that on the territory which in the 19th century belonged to Prussia the Prussian mining legislation ${ }^{2}$ remained in force, etc. The New Polish Mining Act (further referred to as the PMA of 1930) was enacted, by way of the Regulation of the President of Poland, not until 30 November $1930^{3}$. It referred only to minerals of basic meaning for the economy and as a result some kinds of minerals (like sand, clay, some stones, peat etc.) could be mined without application of the PMA of 1930. The basic institution of that new law was the mining property. It could be granted by the Head of the Higher Mining Authority and as a rule - could be obtained by anyone who was able to acquire a land property. The basic exceptions concerned the foreigners. According to the Act of 24 February 1920 on purchase of a land property by foreigners, they could acquire a land property, as well as a mining property, only after the permit granted by the Ministry of Inner Affairs. On the other hand, the mining property of mineral deposits of particular importance for the economy could be obtained only by the state (in fact: state enterprises). A mining proprietor had the exclusive right to mine the minerals within the borders of the 'mining field'. This term was considered as a space in the subsurface, where a mining proprietor could perform his exclusive rights. A mining property was considered as a right similar to a land ownership, and as a result it was protected like the latter or could be transferred onto another subject. The legal status of minerals deposits beyond the limits of an existing mining property was not regulated.

The PMA of 1930 contained only a few regulations referring to environmental protection. The most important of them referred to so called 'mining damages', considered as the damages resulting from mining 


\section{New Polish Geological and Mining Law}

operations. As a rule they had to be compensated according to the rules of civil law, which in practice meant full compensation.

The PMA of 1930 did not refer to oil and gas mining. In that sphere, oil (gas) legislation of Prussia, Russia and Austria remained in force until 1953.

After World War II Poland went under soviet influences, that resulted (inter alia) in nationalisation of existing mining property. Since 1946 existing mining property could belong only to the state and a new mining property could be obtained only by the state (in fact - so called 'state enterprises').

On 6 May 1953 the new Mining Decree (further referred to as the MD of 1953) had been enacted ${ }^{4}$. It referred only to the minerals important to the state economy, declaring that the right to mine belonged exclusively to the state and could be performed only by state enterprises. As a result, other subjects (like private companies etc.) could not obtain the right to mine. The new Act introduced limited liability for so called 'mining damages', so the part of the risk of a mining enterprise was put on the victim (sufferer), which meant that a mining enterprise was not liable for the whole damage. In consequence, in many cases payment of the lump sum of the compensation was more profitable for a mining enterprise than the reparation of the damage. It caused a huge deterioration of the environment and its consequences would be noticeable for many years in the future. Although the MD of $1953 \mathrm{had}$ been amended several times, its basic solutions remained untouched until 1989, that is to the end of the socialistic system in Poland. The MD of 1953 did not refer to many minerals that could be mined in open pit mines (surface mining). Their mining, as a rule, could be performed only by so called 'units of social economy' - it was the consequence of the constitutional rule of the dominating role of the state in the economy.

On 1 January 1989 the rule of ,economic freedom' was introduced to the Polish economy. It meant that (as a rule) all kinds of economic activities could be performed by anybody. Although some kinds of economic (industrial) activities did require special permits (licences, concessions etc.), such permits could be obtained by anybody.

The crucial amendments of the MD of 1953, following the rule of ,economic freedom' were proclaimed in 1991, but they did not remove most doubts and inconsequences of its rules ${ }^{5}$.

Journal of Laws, No 29, item 113 (the MD of 1953).

A. Lipiński, J. Otto: Polish Mineral Legislation and Policies in Transition, Journal of Energy \& Natural Resources Law, Vol. 11 no 1, February 1993, p. 17-26. 
On 4 February 1994 the new Geological and Mining Act $^{6}$ (further referred to as the GMA of 1994), based on the market economy rules, was enacted.

The new Act of 9 June 2011 Geological and Mining Act ${ }^{7}$ (further referred to as the GMA of 2011) is replacing the Act of 4 February 1994. After seventeen years it was decided that hitherto regulations in that matter were no longer suitable and there was a need to change some provisions. Moreover, there was a need to implement the aims of the Hydrocarbon Directive 94/92/WE into the Polish law, and instead of adopting a separate Act, it was decided that the appropriate provisions should be included in the GMA of 2011.

The most important changes in relation to the previous Act are as follows: implementation of a new model of ownership of minerals, elimination of various administrative barriers, introduction of tougher safety regulations, a shift of liabilities for damages to the Civil Code (with longer period for claiming the damages).

The whole process of writing and adopting the new Act had lasted for over two years. It was sometimes a very turbulent process and because of some political quarrels the project had almost been rejected. Unfortunately, the declared simplification and liberalisation must be in fact considered only as a symbolic one.

\section{Scope of the new GMA of 2011}

First of all the GMA of 2011 refers to:

- geological operations,

- mining of minerals,

- underground tankless (non-reservoir) storage of substances (like hydrocarbons),

- using underground as waste landfills,

6 First official promulgation, Journal of Laws, No 27, item. 96 with amendments (GMA 1994), in force since 1 September 1994. 


\section{New Polish Geological and Mining Law}

- protection of minerals, underground waters and other components of the environment associated with the above mentioned activities (article 1).

The Act also refers to some specified kinds of underground activities (like mining scientific activity, maintenance and liquidation of draining system of the closed mining plants, functioning of some historical underground mining plants etc.).

The New Act does not apply to a sands and gravels extraction by a private party, provided that, at the same time, inter alia:

- the activity will be performed within the borders of a land owned by such a person, without use of explosives and must not change the purpose of a land,

- the amount of mineral extracted will not exceed $10 \mathrm{~m}^{3}$ per calendar year,

- the mineral extracted shall be used only for the needs of the landowner (article 4).

Prior notification to the competent authority is required.

\section{Legal status of mineral deposits}

For many years there were no rules referring to the legal status of mineral deposits, first of all answering the question who owns them. The GMA of 1994 introduced theoretically a simple rule, but in practice resulting in numerous doubts. Deposits that remained within the borders of a landownership belonged, irrespective of the kind of a deposit, to a landowner. All other mineral deposits that did not constitute components of a land property were proclaimed as the property of the State Treasury (article 7 of the GMA of 1994). The problem is that in the Polish law a landownership is considered only as a superficial part of the land (earth crust) and it is very difficult to answer the question how 'deep' under the surface are the limits of the landownership (articles 46 and 143 of the Civil Code ${ }^{8}$ ). The reason of such an unclear and ambiguous rule is very simple. It was established in the communist period, under the rules of the MD of 1953, when the right to mine belonged exclusively to the state and the state had the monopoly

8 Act of 16 April 1964, Journal of Laws, No 16, item 93 with amendments. 
of almost all economic activities. On the other hand, a private land property could be expropriated in a very simple way, for a symbolic compensation, much lower then the real value of the land.

The new GMA of 2011 stipulates that determined kinds of mineral deposits of crucial importance for the economy, like hydrocarbons, coal-bed methane, hard coal, lignite, ores of metals, salts, sulphur, as well as gypsum, anhydrite, all seabed deposits existing in Polish marine areas etc., are the subject of ,mining property' belonging exclusively to the State Treasury. All other mineral deposits belong to a land owner (article 10).

The State Treasury, as the exclusive owner of the above minerals, by way of a contract, may establish so called 'mining usufruct'. It is considered as the exclusive right, first of all to mine mineral deposits that are within its limits. One who has explored and documented the deposit of a mineral considered as the 'mining property' has the priority in demanding the establishment of the mining usufruct (article 15 of the GMA of 2011). The establishment of the mining usufruct may be preceded by the collection of tenders. Different rules refer to hydrocarbons.

The above construction means that mineral rights are evolving from the property rights. As a result one who intends to mine (conduct prospective activity) must obtain the right to the space (area) where such an activity is to be performed. That right is the landownership (or evolving from the landownership - such as a lease, usufruct) or it is a mining usufruct.

\section{The GMA of 2011 as environmental law}

The main kinds of activities regulated by the GMA of 2011 are geological operations (first of all referring to prospecting for minerals) and mining. It is out of doubt that minerals are components of environment (in most cases of non-renewable character) and as a result mining of minerals must be considered as the exploitation of the resources of environment. On the other hand geological and mining activities may result in numerous and sometimes long-lasting harms to other components of environment. One may conclude that for that reason many rules of the GMA of 2011 may be considered as protecting environment. 


\section{Economic freedom and geological and mining operations}

Since 1997 the freedom of economic activity is one of the constitutional rights (article 20 of the Constitution). It means that such activity may be carried out, with very few exceptions, by everyone (private person, private company, state-owned company, company with foreign participation etc.). Some kinds of economic activities of special importance for the State, strictly determined by law, require a concession. It is granted as an administrative decision. The exceptions when a concession may be refused or be granted in a reduced scope are provided by law and refer first of all to the environmental protection and public security 9 .

The concession is required, inter alia, for:

- prospecting of mineral deposits that are the subject of mining property,

- exploration of minerals (with few exceptions),

- underground tankless (non-reservoir) storage of substances (like hydrocarbons etc.),

- underground storage of waste.

Although other kinds of activities regulated by the GMA of 2011 may be carried out without concession, they remain under supervision of the State.

\section{Concession authorities}

A concession is an administrative decision, granted by a so called 'concession authority'. Depending on the kind of activity, its size, kind of a mineral, concession authorities are:

- minister competent for the environment,

- marshal of the voivodeship,

- starost.

According to the Act of 3 October 2008 on Access to Environmental Information, Public Participation in Environmental Protection and

9 Economic Activity Act of 2 July 2004, Journal of Laws of 2010, No 220, item 1447 with amendments. 
Environmental Impact Assessments ${ }^{10}$ (further referred to as the EIA) almost all mining projects and many geological projects are considered as ,projects harmful for environment'. The above Act implements the Directive 85/337 on the Assessment of the Effects of Certain Public and Private Projects on the Environment. The Polish model of the EIA has been separated from 'common' administrative procedures and as a result the effect of the EIA is a separate "decision on environmental conditions of the project'. It is a substantial part of the applications for numerous decisions (permits) necessary for carrying out projects considered as ,harmful to the environment'. It refers to concessions on the activities regulated by the GMA of 2011. The environmental conditions provided by the decision on environmental conditions of the project are binding for the concession authorities. Because of a very complicated and long-lasting procedure preceding decision on environmental conditions of the project, its granting is very difficult. The decision on environmental conditions of the project in most cases becomes the substantial part of the concession application and is binding for the future concession.

\section{Co-operation in concession procedure}

Concessions for geological and mining activities are never an unaided decision of a concession authority. Depending on the place of the activity, its kind, the kind of a mineral,the concession must be preceded by an opinion or approval of another authority (authorities). For example concession:

- for off-shore operations (exploration, mining etc. in Polish marine areas) requires approval of the head of marine authority or the minister of marine economy,

- for mining of minerals that are the subject of mining property requires approval of the minister of economy,

- for mining of minerals in on-shore deposits requires approval of the head of the municipality,

- for on-shore exploration activity requires opinion of the head of the municipality. 
Proceedings in the above matters are relatively simple. The concession authority applies for the above standpoint (opinion or approval) of so called 'co-operating authority'. If within 14 days the latter will not grant its standpoint, it is presumed as the lack of objections (article 9 of the GMA of 2011). The problem is that it is very difficult to determine the criteria on which the standpoint of the co-operating authority should be based. Only in one case they are determined by law. Such a situation refers to the approval of the head of the municipality. It must be based on the local development plan; if such a plan does not exist - on the 'local development studies' or other acts determining the destination of the land. According to article 7 of the GMA of 2011 projected operations must not violate such determined destiny of the landownership (article 7, article 23). The problem is that a local development plan is an act of a local law, but it is not compulsory. As the act of a local law it is promulgated in the relevant official journal. On the other hand the local development studies are obligatory, but it does not have the character of the local law act. In fact its function is to determine the policy of the development of the community and is not promulgated. It is not clear how to understand the rule that the intended operations must not violate the purpose of the landownership. The answer is very simple if the question refers to the operations that are to be carried out within the limits of the landownership, for instance if the concession for the superficial (open pit) mining is considered. It is obvious that in such case local development plan that does not determine such piece of land for mining activity results in the refusal of such approval, what makes granting of the concession impossible. The question yet arises in case of underground mining or mining performed by drilling rigs (like shale gas). Under the rules of the GMA of 1994 such approval was to be granted 'on the base of the local development plan' (of 'study', article 16 section 5 of the GMA of 1994). Judgements of administrative courts have been different. In some cases they approved the idea that the local development plan determines only the purpose of the landownership considered as the superficial part of the earth crust ${ }^{11}$. In another case idea of the planning sovereignty of the municipality, referring to the deposits situated hundreds meters below the surface, have been approved. It may be presumed that new rules of the GMA of 2011 will effect that such approval of the concession will be easier and

11 Judgement of the Voivodeship Administrative Court of 2 July 2008, II S.A./Bd $315 / 08$. 


\section{Aleksander Lipiński, Katarzyna Lipińska}

more objective. The background of the above problem is the crisis of local development planning. Only some local communities enacted such plans. What is more, very often they are faulty, for instance do not contain required information of mineral deposits situated there. Both rules referring to the local development plans, as well as the rules referring to environmental protection require from each local development plan to contain the information about mineral deposits existing in that area, as well as to secure the needs of their future mining. Frankly speaking, the above 'co-ordination' is the nightmare of concession procedures and should be simplified. Why had it not happened? It may be presumed, that because of the bureaucratic pressure.

\section{Refusal of concession}

The concession must be refused, if:

- the applicant does not follow the requirements of the law,

- the co-ordinating authority denies approval of the concession,

- intended activity objects the public affairs, inter alia associated with the State security or environmental protection, especially with rational management of mineral deposits or it would effect that the using of land property in the way following its purpose is not possible (article 29 of the GMA of 2011).

It is obvious that concession must not be granted if it has been obtained by another investor.

\section{The contents of the concession}

The contents of the concession depend on kind of the intended operations. Basic rules, common for all kinds of concessions, are as follows. A concession is granted for a specified time, not shorter than 3 years ${ }^{12}$ and not longer then 50 years. It must determine:

- the kind of the intended operation and the way of its performance,

12 Unless the applicant applies for a shorter period. 
- the borders of the area where it may be performed,

- the time of the beginning of the operation.

A concession may determine specific conditions of the intended activity, in particular referring to environmental protection (for instance the amount of the mineral mined, restrictions referring to the explosives). What is the most important $-\mathrm{a}$ concession does not release from the obligations provided by other rules of law, in particular referring to environmental protection, like the need to obtain necessary decisions referring to water protection, air protection, waste management etc. (article 30).

A mining concession creates:

- a mining area; it means the space (within the limits of the land property or the mining usufruct), where the mining entrepreneur has the exclusive right to mine and perform the activity that is necessary for that purpose,

- a so called mining protective area, considered as space influenced by the harmful results of the mining activity; where special rules of using the land property must be applied, especially for building purposes ${ }^{13}$.

Information about the mining area, as well as about the mining protective area is included in the register kept by the Ministry of Environment and is available to the public.

The one who obtains the concession granted on the base of the GMA is considered an 'entrepreneur' (article 6 section 9). As a matter of fact he should be considered a mining (geological) entrepreneur'. The reason is very simple. The legal term of an 'entrepreneur' may be found in many acts, but some of them define it for their own purposes (like Civil Code, Economic Activity Act, etc.). As a result if someone speaks about the 'entrepreneur' in a legal sense, it is necessary to add in the meaning of which act.

\section{Succession}

In some cases another investor may succeed the rights granted by the concession. It may be resulting from many events, like for instance division of same legal persons, unification of companies (limited liability, joint

13 Like strengthening of buildings. 
venture) or the sale of the enterprise. In such case the new entrepreneur must inform concession authority within 30 days.

The new GMA of 2011 holds hitherto rules on specific transfer of the concession between two subjects of law. It happens as the result of the decision of the concession authority. Its main premises are, as follows:

- the consent of the hitherto entrepreneur (the one who holds the concession),

- the applicant's approval of all duties referring to the concession activity and (as a rule) he need to have the right to the land property (or mining usufruct) necessary for performing the intended activity or the promise of their acquisition.

Concession authority may refuse such transfer only if:

- the applicant does not follow the above requirements, or

- such transfer would be violating public affairs or the requirements of environmental protection, especially associated with rational management of mineral deposits (article 36).

\section{Termination of the concession}

The concession terminates:

- after the period of time specified in it,

- if it becomes objectless,

- in the case of the death of the entrepreneur that was a natural person or liquidation of the entrepreneur that was a legal person,

- in the case of the surrender of the concession.

If the entrepreneur violates the requirements provided by:

- the GMA of 2011, especially referred to the environmental protection or rational management of the mineral deposits,

- the concession,

- the concession authority warns and calls for cessation of such violations. If it is necessary the way and time of such cessation may be determined by the decision.

The loss of the concession, irrespective of the way it happens, does not release the entrepreneur from the performance of obligations referring to the environmental protection and closing down of the mining plant. The scope and the way of the performance of such duties are determined by the 
decision of the concession authority. If the entrepreneur exists no more (as a subject of law) and his duties has not been succeeded by anyone, as a rule such duties are the burden of the landowner (article 39).

The initiating of the concession operations is considered as having irreversible legal effect. It means that in such case the concession must not be nullified. Similar rule refers to the resumption of the administrative procedure; in such case if the activity has been initiated, the amendment or revocation of the concession must not happen after one year (article 42). The above rules follow solution provided by some other Acts referring to the projects of specific character ${ }^{14}$ and their function is the protection of geological and mining investments. It means that if the concession would be considered as wrong, violating law, it must not be nullified, revoked or amended, although it does not remove the compensation for damages.

\section{Hydrocarbons}

Specific rules refer to the concessions for exploration for and exploitation of the hydrocarbons (articles 43-49). The intention of such regulation is full implementation of the Directive 94/22/EC of the European Parliament and of the Council of 30 May 1994 on the conditions for granting and using authorizations for the prospecting, exploration and production of hydrocarbons ${ }^{15}$. The Commission considered hitherto the GMA of 1994 as not fully implementing the above directive ${ }^{16}$.

\section{Professional qualifications}

The one who performs some specific functions (professions), both in mining and geology, must poses specific qualifications, considered as education and experience. Details are very complicated and there is no need to present

14 Like road construction, construction of some railways etc.

15 Official Journal L 164, p. 3-8.

16 Case C-569/10, claim brought on 3 December 2010 r. (the Commission v. Republic of Poland). 
them in this article. It is worth saying that the above functions, inter alia, refer to environmental protection in mining plants (articles 50-78 of the GMA of 2011). Functions requiring such qualifications shall be determined by the operation plan of the mining plant.

\section{0ther geological operations and geological records}

Geological operations referring to exploration of mineral deposits that are the subject of mining property require exploration concession. With few exceptions other geological operations conducted below the surface require the decision approving the draft of geological exploration. The most important effect of geological operations must be presented in ,geological report'. It should describe the results of the geological operations (prospective etc.) and their interpretation. There are three basic kinds of such reports, referring to:

- mineral deposits (providing information about the existence of such deposits, their structure, borders, capacity, environmental problems of future exploitation etc.),

- hydro-geology (proving information about the existence of underground waters, characteristic and capacity of the aquifers, properties of waters etc.),

- engineering (providing information necessary for building constructions, local development plans, waste landfills etc.).

Details referring to the contents of such reports are determined by the regulations of the Ministry of Environment.

A geological report must be approved by the decision of the 'geological authority' - depending on the kind, size of activity and other circumstances, these are: the minister competent for the environmental issues, the marshal of the voivodeship and the starost. A geological report provides so called geological information. The one who applies for the mining concession, as well as for the concession for underground storage of substances or using underground as landfills of wastes, must prove the 'right to use the geological information'. The rules referring to this right are very unclear. First of all 'the right to geological information' always is vested to the State Treasury, irrespective who has beard the cost of geological works, which may be considered as sui generis quasi-nationalisation. The one who on the base 
of necessary decisions conducted geological operations and covered their costs has the right to free exploitation of such obtained information, first of all for the purposes of concession procedures. If the right to geological information is vested exclusively to the State Treasury, it may dispose it. Such disposal for the purposes of:

- mining concession,

- concession for underground tankless storage of substances,

- concession for using underground as landfills of wastes,

- water permits

is payable, while for other purposes it is free (article 99 of the GMA of 2011).

Geological information, first of all contained in relevant geological reports, plays a great role in environmental protection and local development. In fact, such information may be considered as environmental information. As a result of the above rules local communities may use geological information for constructing their development plans. The GMA of 2011 requires information on mineral deposits, contained in relevant geological reports, as well as information on underground waters, to be disclosed in local development plans. In fact it is the repetition of hitherto rules. The novelty of the GMA of 2011 is that such information must be disclosed in local development study within two years since the geological report has been approved. If the municipality does not follow the above obligation and does not amend its local development study, the voivode must amend local development study, introducing such information in it, on the expense of the municipality (articles 95-96). Such 'disclosure' does not mean that the pieces of land in which mineral deposits exist will be destined for the mining purposes. As a rule such destination may result only from the local development plan. Mining concession must be granted with the approval of the head of the municipality, based on the ground of the local development plan. If such plan does not exist ${ }^{17}$, the approval should be based on the 'local development study'. The problem is that in many cases both plans and stadiums do not contain any information about existence of mineral deposits and as a result in some cases granting of the concession may be impossible.

17 As a rule local development plans are not compulsory. Planning procedure is very long, complicated and expensive and as a result only some parts of the country are covered by such plans. 
For that reason the GMA of 2011 provides that if the geological report has been approved according to the hitherto rules, but the information about the deposit had not been introduced into local development study, council of the municipality must fulfil that duty within 2 years. If not, the voivode must amend the local development study, on the cost of the municipality (article 208).

\section{Local development plan for mining}

Existence of the mineral deposits and their exploitation, in particular the underground methods, causes numerous problems for the environment. The devil is in the numerous details, like the depth of the mining, structure of the deposit and the environment around the deposit, size and system of mining etc., which may result in various influences for the environment, in particular in building areas. It is very difficult to find legal instruments, which may allow for the reconciliation of such contradictory interests. The concession may determine particular duties referring to environmental protection, but considering the fact that the concession may be granted even for 50 years, the reasonable determination of such duties may be impossible. First of all the GMA of 2011 provides that both mining area and mining terrain must be disclosed in the local development study and the local development plan. If it may be presumed that the activity determined by the concession may result in a significant impact to the environment, the local development plan for the mining terrain may be enacted. Apart from the requirements resulting from the rules referring to the development plans, such plans should also ensure the integration of all activities within the mining terrain, conducted for the:

- performance of the concession activity,

- public safety,

- protection of the environment, as well as buildings.

In particular such plan may determine:

- a mining pillar, considered as the part of mining area where mining operations, because of the need of the protection of determined objects or territories, may be banned or allowed only under special circumstances, 


\section{New Polish Geological and Mining Law}

- territories where building is prohibited or allowed only under special circumstances.

Costs of such restrictions, as well as the costs of the project of such local development plan, are covered by the entrepreneur (article 104).

According to the Act of 27 March 2003 on Development Plans the local development plan in considered as the act of local law, universally binding on its territory. As a result:

- all administrative decisions (with some exceptions) referring to such territory must follow rules of such plan; in particular it refers to the building permits or decisions approving mining operation plans,

- municipality has been granted very powerful instrument that may regulate the influences of mining activities.

On the other hand, it is worth mentioning that in fact the above article 104 provides only insignificant amendments of hitherto rules. Although the old GMA of 1994 provided that (as a rule) such local development plan for the mining terrain had to be enacted, only few such plans had been enacted $^{18}$. In hitherto law the mining entrepreneur had not been obliged to cover the costs resulting from building bans that could be introduced on mining terrains.

\section{Operation of the mining plant}

Numerous rules of the GMA of 2011 (as well as in the case of all hitherto mineral legislation, as well as in other countries) refer to operation of mining plant. Mining plant has been defined as the separated complex serving directly for the mining of the mineral deposit, in particular mining excavations, buildings, technical devices and installations; it does not refer only to the mining of the minerals, but for some other kinds of underground activities (underground storage of substances, underground waste landfills). In the plants used for hard coal mining its objects are buildings, installations etc. used to the preparation of the mineral mined for selling (article 6 point 18). It is worth knowing that mining plant operations are performed in the environment that usually is unfamiliar to people, where many threads

18 Most of them were violating the law. 
unknown at the surface may occur (like methane explosion, hard coal dust explosion, radioactive influence, falling of rocks, etc.). As a result special standards of security are necessary.

\section{Mining plant operations}

First of all, the operations of the mining plant must be carried out according to the rules of law and the mining technique, in particular according to the mining operations plan. The above plan is not required in so called 'simple cases', for example when the entrepreneur is carrying out his operations on the basis of the concession granted by the head of the county.

Mining plant operations plan is drafted by the entrepreneur, separately for each mining plant. Such plan determines:

- framework of the mining plant (in particular its divisions, posts requiring special professional qualifications),

- detailed requirements necessary for ensuring:

- concessions operations,

- public safety, fire safety,

- safety of the people remaining in the mining plant, first of all referring to the safety of work,

- rational management of the mineral deposit,

- environmental protection,

- protection of buildings,

- prevention of damages and their compensation.

Details of such plans, depending on the kind of the activity, are determined by the regulation of the minister competent for the environment.

As a rule such plan is drafted for the period from 2 to 6 years and is approved by the decision of the mining authority, after presenting an (non-binding) opinion of the head of the municipality (article 108).

The above decision must follow the provisions of the concession as well as of all acts of law. Since the local development plan is the act of local law, it determines the contents of the mining operations plan. It means that the local authorities, first of all the council of the municipality, may have great impact on such plan. 


\section{New Polish Geological and Mining Law}

Operations of the mining plan must follow the rules determined in such plan. The renouncement of such plan is allowed only if there is a thread to the:

- safety of the mining plan (its part),

- public safety,

- environment.

In such case the entrepreneur must immediately inform the mining authority and the head of the municipality and undertake operations necessary for the protection of human health and safety, public safety and the environment. If it is necessary, mining authority, by the way of the decision, may determine details referring to the above duties. Such decision must be executed immediately.

Mining operations must be managed and supervised by the people who obtained necessary 'mining' professional qualifications. Posts in the mining plant requiring such qualifications are determined by the mining operation plan (articles 111-112).

The problem is that two different mining plants while extracting the same mineral, even if in the same way (in particular if it happens by the way of underground operations), may operate in quite different mining conditions, which strongly influence the safety standards. It means that the details determining the safety standards may be quite different and the simplest way is their individual determination, by the way of the mining operations plan.

In mining plant only so called 'safe products' may be used (article 113).

Special rules associated with the mining plant are referring to:

- explosives,

- rescue operations.

First of all acquisition of explosives, as well as their storage and using, depends on the permit granted by the mining authority ${ }^{19}$. The same organ is competent if the explosive equipment is to be acquired, stored and used.

The entrepreneur who extracts the mineral from deposit is obliged to:

- keep so called 'geological and mining surveying records' (details are determined by the regulation of the ministry in charge of the environmental issues),

19 See Act of 21 June 2001 on the explosives destined for the civil purposes, Journal of Laws, No 117, item 1007 with amendments. 
recognise threads associated with the mining operations and undertake necessary precautionary measures.

Such 'geological and mining surveying records' determine the changeable situation of the mining plant in the environment, and must be considered as the specific kind of the environmental information. They may be prepared only by so called 'geological and mining surveying service', consisting of the people who posses specific professional qualifications. The above mentioned records must be kept up-to date. If it is necessary, their supplementation must be ordered by the mining authority (article 116). After closing-down of the mining plant the above records shall be delivered to the Higher Mining Authority and are considered as the public environmental information. The fact that the information about the way of the liquidation of the mining plan is publicly available means that the status of the environment influenced by the mining operations may be easier to determine. It means, inter alia, that such information (contained by the above records), must not be ignored in the procedure of drafting the local development plan. Although the above rule repeats the solution that at least partially is known since 2 September $1994^{20}$, the practice still ignores it. Only few local development plants keep the above information in mind.

\section{Rescue operations}

Specific rules refer to the mining life-saving operations in a mining plant.

Mine rescue operations may be performed by the entrepreneur who:

- has been granted the concession (so called 'own rescue service'),

- provides professional 'rescue operations'.

Details referring to such 'rescue service', first of all to its organisation and equipment, are determined by the regulation of the minister responsible for the economy.

Each mining plant should have its own 'rescue operation' plan, approved by the head of the mining plant. Mining authority may order:

- the amendments of such 'rescue operation' plan, as well as the supplementation of the equipment of mine rescue service.

20 The date when GMA1994 entered into force. 
Details referring to the mining plant, especially to:

- its operations,

- storage and using of explosives,

- rescue operations (its equipment, organisation etc.)

- are determined by the regulations of the minister responsible for the economy, sometimes by the regulations of the minister in charge of the environmental issues (articles 114-124).

\section{Underground landfills}

Specific rules refer to the underground facilities used as wastes landfills. Such landfill is considered as the mining plan and as a result its operation must follow the relevant rules of the GMA of 2011. The main rules of that Act determine:

- kinds of underground disposal facilities,

- bans for putting some specific kinds of wastes to the underground object.

Such 'underground landfill' must follow all 'general rules' (of safety) referring to the underground mining plants. Further details will be omitted in this article.

\section{Closing-down of a mining plant}

Specific rules refer to the 'closing-down of a mining plant'. First of all, the entrepreneur who has been granted the concession (except the exploration concession) must establish so called 'mining plant liquidation fund'. Its means should be kept on the separate bank account. Details such as the way the fund is to be created may be omitted. The entrepreneur may create one fund for all his mining plants. The means of such fund may be used only for covering the liquidation costs. The money collected on such fund may be withdrawn only after presentation of the decision approving the operation plan of the closing-down of the mining plant and used only for the closingdown purposes. Liquidation of such fund requires the permit of the mining authority (article 128). 
If the mining plant is to be closed down, the entrepreneur is obliged to:

- secure or liquidate the mining excavations, installations, machinery and other objects of the mining plant,

- secure the remaining part of the mineral deposit and the neighbouring deposits,

- protect the excavations of the neighbouring mining plants,

- protects the environment and re-cultivate the land influenced by the mining activity.

Details are to be determined by the mining operation plan of the closingdown plant, confirmed by the mining authority, after the approval of the head of the municipality (article 129).

Specific rules refer to hard-coal mines. In some cases drainage systems of such mining plants must be kept in operation for a very long time after the mining has stopped. The reason is very simple. Very often underground mining plants are quite close to each other and there are numerous water links between them. If one such plant is closed-down, enlarged mine water inflow in other mining plants may occur. On the other hand, longlasting underground operation may results in lowering of the surface, and stopping of mining drainage may cause threads for the building standing there. As a result in some cases drainage must be conducted. Some details referring to such problems may be found in the Act of 7 September 2007 on hard-coal mining management in the years 2008-2015 ${ }^{21}$. Costs of such drainage maintenance are covered by the State Treasury.

\section{Environmental Fees}

According to the Act of 27 April 2001 on Environmental Protection ${ }^{22}$ fees stipulated by the Geological and Mining Act are considered as a specific kind of environmental fees.

Part VI of the GMA of 2011 deals with financial fees for mining activities, which are royalties, concession fees (both these two groups of charges are sometimes referred as royalties) and financial sanctions. Royalty is charged for extracting minerals from deposits, while concession fees for: prospecting, exploration of mineral deposits, underground non- 


\section{New Polish Geological and Mining Law}

reservoir storage of substances in the subsurface and underground storage of waste.

An entrepreneur who has obtained a concession for prospecting or exploration of mineral deposits shall pay a concession fee, determined in the concession as the product of the fee rate and the number of square kilometres of the area on which the activity is carried out. The rates of such concession fee are determined in the Act and depend on the kind of the mineral. The concession fee for this kind of activity is paid only once (article 133).

An entrepreneur who has obtained a concession for underground nonreservoir storage of substances in the subsurface or underground storage of waste shall pay concession fee calculated as the product of the fee rate and amount of substances or waste injected in the calculation period to the subsurface, including underground mining excavations. Rates are determined in the Act (article 135).

An entrepreneur who has obtained a concession for extracting minerals from deposits shall pay the royalty calculated as the product of the royalty rate and the amount of the mineral mined from the supposed economic (balance) and sub-economic deposits, in the calculation period. There used to be $^{23}$ (maximum and minimum) rates of royalties designed in the Act and unit rates in the regulation of the Council of Ministers. This manner was abandoned and now rates of royalties for individual kinds of minerals are specified in the Annex of the Act. For the accompanying mineral exploited and the accompanying mineral exploited from the hydrocarbon deposits the $50 \%$ of royalty rate shall be calculated. The entrepreneur shall calculate the royalty (concession fee) on his own every six months (previously, it used to be a period of every quarter) and pay it, without being called on to do so, to the bank accounts of the receivers. However, if the royalty (concession fee) in a calculation period does not surpass the amount of PLN $300^{24}$, the obligation of payment does not occur (it is a new provision compared with the previous Act).

If the entrepreneur does not meet the obligation to pay the royalty or he does pay the wrong amount, the concession authority shall issue a decision in which it shall set the amount of the due royalty, using the rates in effect in a proper calculation period.

23 According to GMA 1994.

24 About 70 Euro. 
If the activity is conducted in gross violation of the conditions of the concession, by way of a decision, the competent authorities shall establish an additional (penal) royalty.

If the activity is conducted without the required concession, by way of a decision, the competent authorities shall establish a royalty in a higher (penal) amount (it is 40 times higher that the normal royalty rate).

In general $60 \%$ of all the above fees is assigned for the income of the municipality on the territory of which the activities covered by the concession are carried out, and $40 \%$ of them is the income of the National Fund for Environmental Protection and Water Management. It has not changed compared with the previous Act, but it is worth to mention that the government did proposed to assign the $90 \%$ of fees for the municipality and only $10 \%$ for the National Fund. Such suggestion was an attempt of ,trade' with local authorities and their representatives so that they accept the provision about the underground excavations ${ }^{25}$. On the other hand, that proposal was fiercely opposed by geologists ${ }^{26}$.

If the activities are conducted in the territories of more than one municipality, the fees shall constitute the incomes of these municipalities; in proportion to the size of the space covered by the activities, the amount of the mineral exploited, the amount of substances or waste injected to the subsurface. If the activities are conducted within the boundaries of the maritime areas of the Republic of Poland, the due charges shall constitute the sole income of the National Fund for Environmental Protection and Water Management. A new solution is that a royalty in a higher amount, while determined by the head of the county administrator, shall constitute the income of the district.

25 One of the biggest controversies during the parliamentary work over new Act was the governmental trial of regulation of taxation of underground excavations and installations located in such excavations. In the first governmental draft there was a provision (article 6 section 2) that "underground mining excavations and installations and appliances located there, are neither structures nor building facilities in terms of the building law". This provision was vigorously opposed by the representatives of the local authorities; they claimed that it was unlawful attempt to deprive the municipalities of their legitimate rights and money. The government and representatives of the mining industry stated that the aim of such provision was to remove the doubts concerning the issue of taxation of the underground mining excavations and the infrastructure located in such excavations, because the provisions based on which the municipalities tried to tax the excavations were very imprecise.

26 One of the main purposes of the National Fund for Environmental Protection and Water Management is financing of some geological works. 
There is also a provision of a 5-year period of prescription. In other cases the provisions on tax obligations regulated by the Tax Ordinance $\mathrm{Act}^{27}$ shall be applied mutatis mutandis.

\section{Liability for “Mining” Damage}

Comparing to the previous Act, there are more civic solutions in the new Mining and Geological Law, which means that it is the aggrieved party that decides about the method of reparation of the damages.

The general rule in the Polish law is that the owner may not object to the threats caused by mining plant operations, if such operations take place in accordance with the Act. However, the owner may demand to repair the damage caused by these operations in accordance with provisions of this Act. Such damage shall be rectified pursuant the provisions of the Civil Code, unless the Act provides otherwise. In other circumstances, not indicated in the Act, the provisions of the Civil Code shall be also applied. It means that the liability of the mining entrepreneur is based on article 435 of the Civil Code (liability on basis of risk). The one who suffers the damage does not need to prove the fault of the mining entrepreneur. Moreover, the mining entrepreneur is liable for the mining damage even if he follows all rules of law and is not guilty.

It is an entrepreneur conducting mining plant operations who, as a rule, shall be liable for the damage.

If the party that caused the damage cannot be identified, the entrepreneur who is authorized, at the time the damage occurs, to conduct the activity regulated by the Act within the boundaries of the mining area, shall be liable for it.

Moreover, in case of the absence of the entrepreneur liable for the damage or its legal successor, the State Treasure, represented by the competent mining supervision authority, shall be liable for it.

If the damage occurred for reasons other than the mining plant operations, the parties indicated above shall be liable jointly and severally.

27 Act of 29 August 1997, Journal of Laws of 2005, No 8, item 60, with amendments. 
There is a new provision in this part of the Act about the period of prescription: the claims specified in this part may be submitted in a 5-year period since learning about the damage (articles 144-149).

The above rules shall be also applied, mutatis mutandis, for preventing the mining damages (article 150).

Another rule referring to liability for damage says that court litigation shall be possible only when conciliatory proceedings have been exhausted. As a rule there are 30 days for such conciliation.

\section{Authorities}

According to article 156 the geological administration authorities are:

- the minister competent for the environment, assisted by the Chief Geologist of the Country, being the secretary of state or undersecretary of state in the Office servicing the minister,

- marshals of voivodeships, assisted by voivodeship geologists,

- starosts, assisted by powiat geologists.

Their main tasks are:

- deciding about the matters covered by the GMA (with exceptions of the matters in which mining supervision authorities are competent), like granting concessions, approval of geological reports etc.,

- control and supervision over the activities regulated by the GMA (with exceptions of the matters in which mining supervision authorities are competent).

According to article 164 mining supervision authorities are:

- President of the State (Higher) Mining Authority ${ }^{28}$,

- directors of the regional mining authorities,

Director of Specialized Mining Authority.

The President of the State Mining Authority is the central authority of the governmental administration, appointed (and dismissed) by the Prime Minister and supervised by the minister competent for the environment. In fulfilling his duties, the President of the State Mining Authority is assisted 
by the State Mining Authority, working under his direct management. Its seat is in Katowice.

The territorial authorities of governmental administration subordinated to the President of the State (Higher) Mining Authority are the directors of the regional mining authorities and Director of Specialized Mining Authority, in both cases appointed by the President of the State (Higher) Mining Authority. With few exceptions, these are authorities considered as competent in the first instance.

The mining supervision authorities exercise supervision and inspection over mining plant operations, in particular over work safety and health, fire safety, mine rescue, management of mineral deposits during their exploitation, environmental protection, including damage prevention, mining plant construction and closing down, including land reclamation and development of post-mining areas.

\section{Penalties}

There are new provisions, introduced to the Act by the Senat, concerning the President of the State (Higher) Mining Authority's powers to impose penalties. Such penalties are imposed, by way of a decision, on entrepreneurs or managers of the mining plant operations, who have not fulfilled the legal obligations, especially concerning safety of the mining plant operations. The penalty imposed on an entrepreneur is an equivalent of $3 \%$ of an income of the punished entity, and an equivalent of $300 \%$ of monthly salary in case of a manager of the mining plant operation (article 175).

\section{Penal Provisions}

There is no substantial change in this part of the Act. Hitherto regulations concerning model, scope and penalties of criminal liability are kept almost intact. There are fourteen articles describing penalties for offences concerning mining and geology. For the purpose of this article the following examples would be enough. 
The one who without the concession or without project of the mining works or violating their conditions while conducting the activity such as:

- prospecting or exploration of mineral deposits,

- extracting minerals from deposits,

- underground non-reservoir storage of substances in the subsurface and underground storage of waste,

- cause damage to property or great damage to the environment, shall be liable to imprisonment for up to 3 years.

If the perpetrator of the above deeds causes direct danger or substantial damage in property or great damage to the environment, he shall be liable to fine, restriction of freedom or imprisonment for up to 2 years. If such deeds are caused unintentionally, the perpetrator shall be liable to fine, restriction of freedom or imprisonment for up to a year.

The one who without the concession or without project of the mining works or violating their conditions conduct the activity such as:

- prospecting or exploration of mineral deposits,

- extracting minerals from deposits,

- underground non-reservoir storage of substances in the subsurface and underground storage of waste,

- shall be liable for a fine or penalty of an arrest.

Judgement in the matters enumerated in this part of the Act shall be passed according to the Misdemeanour's Procedure Code (articles 176-189).

\section{Interim and Final Provisions}

This final part of the Act is very important and concerns the continuity of functioning of the entrepreneurs and other parties obliged to apply hitherto the GMA of 1994. There are provisions regulating some changes in terminology, the binding force of the hitherto regulations, agreements, rights, concessions and decisions according to the GMA of 1994. The new GMA of 2011 shall come into force on 1 January 2012, what means that there was almost 6-month vacation legis. 